\title{
PENGARUH MODEL LEARNING CYCLE TIPE 7E DISERTAI TEKNIK TALKING STICK TERHADAP SIKAP ILMIAH SISWA PADA MATERI PROTISTA
}

\author{
Laila Puspita $^{1}$, Haris Budiman ${ }^{2}$, Meivi Aldona Thessalonica ${ }^{3}$ \\ ${ }^{1,2,3}$ Mahasiswa Jurusan Pendidikan Biologi Universitas Islam Negeri Raden Intan Lampung \\ E-mail: lailapuspita@ radenintan.ac.id
}

Diterima : 15 Oktober 2018. Disetujui: 22 Novemver 2018. Dipublikasikan: 29 Desember 2018

\begin{abstract}
ABSTRAK
Penelitian ini bertujuan untuk mengetahui pengaruh model Learning Cycle Tipe $7 E$ disertai teknik Talking Stick pada materi protista terhadap sikap ilmiah siswa kelas X SMA Negeri 8 Bandar Lampung. Metode penelitian yang digunakan adalah Quasi Eksperimen, dengan Posttest Only Control Design. Pengambilan sampel dilakukan dengan menggunakan Cluster Random Sampling. Pengambilan data menggunakan instrumen berupa angket dan lembar observasi sikap ilmiah dan analisis data menggunakan Uji-T Polled Varians. Hasil analisis data menunjukkan bahwa $t_{\text {tabel }}$ $2,437617>t_{\text {tabel }} 1,999624$, maka dalam hal ini $\mathrm{H}_{0}$ ditolak dan $\mathrm{H}_{\mathrm{i}}$ diterima sehingga dapat dinyatakan bahwa terdapat pengaruh model Learning Cycle Tipe $7 E$ disertai teknik Talking Stick pada materi protista terhadap sikap ilmiah siswa kelas X SMA Negeri 8 Bandar Lampung.
\end{abstract}

Kata Kunci : Learning Cycle Tipe 7E, Talking Stick, Sikap Ilmiah.

\begin{abstract}
This study aims to determine the effect of the 7E Type Learning Cycle model along with the Talking Stick technique on protist material on the scientific attitude of class $X$ students at Bandar Lampung Senior High School 8. The research method used was Quasi Experiment, with Posttest Only Control Design. Sampling is done using Cluster Random Sampling. Data retrieval uses instruments in the form of questionnaires and scientific attitude observation sheets and data analysis using the Polled Variance T-Test. The results of data analysis showed that tt 2.437617> t table 1.999624, then in this case HO is rejected and $\mathrm{Hi}$ is accepted so that it can be stated that there is an influence of the $7 E$ Learning Cycle model along with Talking Stick techniques on protist material on the scientific attitude of class $X$ students of SMA 8 Bandar Lampung.
\end{abstract}

Keywords: Type 7E Learning Cycle, Talking Stick, Scientific Attitude.

\section{PENDAHULUAN}

Pada era globalisasi saat ini ketika kemajuan IPTEK semakin pesat, hal ini juga berimbas pada pentingnya seorang guru meningkatkan kinerja dan kemampuan mereka sehingga terwujud keprofesionalan yang mantap (Karweti, 2010; Sanjaya, 2016). Hal ini berarti keberadaan teknologi dan model pembelajaran harus bisa dimanfaatkan oleh pendidik agar proses pembelajaran dapat berjalan efektif (Haryoko, 2012; Rahmawati, Nugroho, \& Putra, 2014). Model pembelajaran merupakan cara-cara yang berbeda-beda 
untuk mencapai hasil pembelajaran yang berbeda di bawah kondisi yang berbeda(Wena, 2009). Penggunaan strategi pembelajaran berguna bagi guru karena strategi dapat dijadikan pedoman dan acuan bertindak yang sistematis dalam pelaksanaan pembelajaran dan bagi siswa penggunaan strategi dapat mempermudah proses belajar. Jadi dapat disimpulkan bahwa strategi sangat berguna bagi keduanya, keberhasilan guru menerapkan suatu strategi pembelajaran tergantung dari kemampuan guru menganalisis kondisi pembelajaran sehingga dijadikan pedoman dalam menentukan strategi pembelajaran yang akan digunakan untuk siswa. Berdasarkan hasil pra penelitian yang dilakukan peneliti di SMA Negeri 8 Bandar Lampung, diperoleh bahwa nilai sikap ilmiah siswa masih rendah, hal ini dapat dilihat pada Tabel 1 sebagai berikut.

Tabel 1

Rekapitulasi Nilai Sikap Ilmiah Siswa

\begin{tabular}{|c|l|c|c|}
\hline No. & \multicolumn{1}{|c|}{$\begin{array}{c}\text { Indikator Sikap } \\
\text { Ilmiah }\end{array}$} & $\begin{array}{c}\text { Rataan Sikap Ilmiah } \\
\text { Kelas Eksperimen }\end{array}$ & $\begin{array}{c}\text { Rataan Sikap Ilmiah } \\
\text { Kelas Kontrol }\end{array}$ \\
\hline 1. & Rasa Ingin Tahu & 68 & 67 \\
\hline 2 & Jujur & 67 & 69 \\
\hline 3 & Skeptis & 66 & 67 \\
\hline 4 & Bekerja Sama & 67 & 68 \\
\hline 5 & Berfikir Kritis & 66 & 69 \\
\hline \multicolumn{2}{|l|}{ Rataan }
\end{tabular}

Sumber : Dokumen Nilai Sikap Ilmiah siswa Kelas X Semester Ganjil Kelas X SMAN 8 Bandar Lampung Tahun Ajaran 2017/2018

Berdasarkan Tabel 1 di atas menunjukkan bahwa terdapat 5 sikap ilmiah yang dinilai yaitu rasa ingin tahu, jujur, skeptis, bekerja sama, serta berfikir kritis. Pada kelas eksperimen rataan nilai sikap ilmiah yang didapat adalah 66, 8 dan pada kelas kontrol rataan nilai sikap ilmiah yang didapat adalah 68 artinya diketahui bahwa rataan perolehan sikap ilmiah yang muncul adalah homogen. Siswa sudah menunjukkan sikap ilmiah yang sudah cukup konsisten tetapi harus di tingkatkan lagi untuk mencapai nilai standar KKM pada nilai afektif siswa jadi dalam hal ini siswa harus mempunyai kesadaran akan proses pembelajaran sains khususnya biologi untuk menekankan sikap ilmiah.

Berdasarkan hasil observasi dan wawancara yang telah dilakukan dengan Ibu Eti Erliyani S.Si selaku guru Biologi kelas X SMAN 8 Bandar Lampung, didapatkan hasil bahwa dalam proses pembelajaran selama ini masih berpusat pada guru (teacher centered). Metode yang sering digunakan yaitu metode ceramah dan hanya beberapa kali memakai metode diskusi, dalam metode ceramah siswa kurang dapat berpartisipasi 
karena hanya fokus mendengarkan dan mereka cenderung pasif karena kurang rasa ingin tahu, sedangkan dalam metode diskusi hanya beberapa siswa yang dapat mengemukkan pendapatnya, namun metode diskusi pun jarang dilakukan karena tidak berjalan secara efektif.

Salah satu alternatif untuk pemecahan masalah tersebut adalah dengan menggunakan model Learning Cycle Tipe $7 E$ disertai teknik Talking Stick. Learning Cycle (pembelajaran bersiklus) adalah suatu model pembelajaran yang berpusat pada siswa (student centered) (Agustyaningrum, 2011; Astutik, 2012; Kulsum \& Hindarto, 2011; Rahayuningsih, Masykuri, \& Utami, 2012; Taufiq, 2012). Di dalam Learning Cycle Tipe $7 E$ terdapat tahapan-tahapan pembelajaran yang tertata dan terkonsep jelas. Sedangkan teknik Talking Stick merupakan teknik pembelajaran yang mendorong siswa untuk mengeluarkan pendapat, bekerja sama dan termotivasi dalam pembelajaran (Ayu Aningrum, 2014; Sugiharti, 2011; Yanuarta, Waluyo, \& Suratno, 2014) dan membuat pembelajaran lebih menyenangkan (Hasan, Ngatiyo, \& Aunurrahman, 2013). Keduanya termasuk kedalam pembelajaran kooperatif, keduanya berkombinasi dapat menciptakan suasana menyenangkan dan membuat siswa aktif. Atas dasar hal tersebut di atas, maka peneliti tertarik melakukan penelitian dengan judul "Pengaruh Model Learning Cycle Tipe 7E disertai teknik Talking Stick Terhadap Sikap Ilmiah Siswa SMA Pada Materi Protista".

\section{METODE PENELITIAN}

Metode yang digunakan dalam penelitian ini adalah metode Quasi Eksperimen. Quasi Eksperimen adalah desain yang memiliki kelompok kontrol sehingga tidak berfungsi sepenuhnya untuk mengontrol variabel-variabel luar yang mempengaruhi pelaksanaan eksperimen (Sugiyono, 2015). Desain penelitian yang digunakan adalah "Posttest-Only Control Design".

Populasi dalam penelitian ini yaitu seluruh siswa kelas $\mathrm{X}$ semester genap Tahun ajaran 2017/2018 SMA Negeri 8 Bandar Lampung. Teknik pengambilan sampel menggunakan Cluster Random Sampling, karena sampel dianggap memiliki karakteristik yang homogen. Adapun berdasarkan undian pengambilan sampel terhadap kelas X SMA Negeri 8 Bandar Lampung didapat kelas X-1 sebagai kelas eksperimen dan kelas X-2 sebagai kelas kontrol. 
Instrumen penelitian yang digunakan meliputi angket (kuesioner), dan lembar observasi. Angket adalah sejumlah pertanyaan tertulis yang digunakan untuk memperoleh informasi dari responden dalam arti laporan tentang pribadinya atau halhal yang ia ketahui (Fu'adi \& Eko, 2009; Sari, 2014; Yumarlin, 2013). Dalam penelitian ini menggunakan angket sikap ilmiah yang telah di validasi oleh para dosen ahli. Angket sikap ilmiah diberikan pada akhir pertemuan. Observasi merupakan suatu proses yang kompleks, suatu proses yang tersusun dari berbagai proses biologis dan psikologis. Dalam penelitian ini juga menggunakan lembar observasi sikap ilmiah yang telah di validasi oleh para dosen ahli. Data yang dikumpulkan melalui observasi adalah sikap ilmiah yang muncul selama proses pembelajaran, pengamatan pembelajaran oleh guru selama pelaksanaan pembelajaran. Analisis data dilakukan dengan menggunakan uji-t.

\section{HASIL PENELITIAN}

Berdasarkan penelitian, uji validitas diketahui nomor butir soal yang valid berjumlah 30 soal dan nomor butir yang tidak valid berjumlah 10 soal. Jadi soal yang digunakan sebanyak 30 butir soal pernyataan. Hasil pengujian reliabilitas diperoleh nilai sebesar 0,85 dengan korelasi sebesar 0,74 dan dapat disimpulkan bahwa data reliabel. Pada kategori sukar terdapat 4 nomor butir soal, kategori sedang terdapat 8 nomor butir soal, kategori mudah terdapat 16 nomor butir soal dan pada kategori sangat mudah terdapat 11 nomor butir soal. Data nilai posttest angket sikap ilmiah pada materi protista dapat dilihat pada siswa kelas eksperimen serta kelas kontrol berikut ini :

Tabel 2

Nilai Angket Sikap Ilmiah pada Kelas Eksperimen dan Kelas Kontrol

\begin{tabular}{|l|c|c|}
\hline \multirow{2}{*}{ Kriteria } & \multicolumn{2}{|c|}{ Nilai Posttest Angket } \\
\cline { 2 - 3 } & Kelas Eksperimen & Kelas Kontrol \\
\hline Nilai tertinggi & 98 & 90 \\
\hline Nilai terendah & 72 & 71 \\
\hline Jumlah & 3276 & 2868 \\
\hline \multicolumn{1}{|c|}{ Rataan } & $\mathbf{8 3}$ & $\mathbf{8 0}$ \\
\hline
\end{tabular}

Berdasarkan Tabel 2 di atas dapat dilihat bahwa nilai posttest yang diperoleh kelas eksperimen dan kelas kontrol memiliki perbedaan walaupun hanya berbeda tipis. Nilai posttest kelas eksperimen yang menggunakan model Learning Cycle Tipe $7 E$ disertai teknik Talking Stick nilai rataan nya lebih tinggi dari kelas kontrol yang menggunakan model Direct Instruction (DI). Untuk nilai rataan posttest kelas eksperimen yaitu 83 dan untuk kelas kontrol nilainya 80. 
Untuk melihat ketercapaian sikap ilmiah siswa melalui angket sikap ilmiah yang diberikan dapat dilihat pada diagram berikut ini :

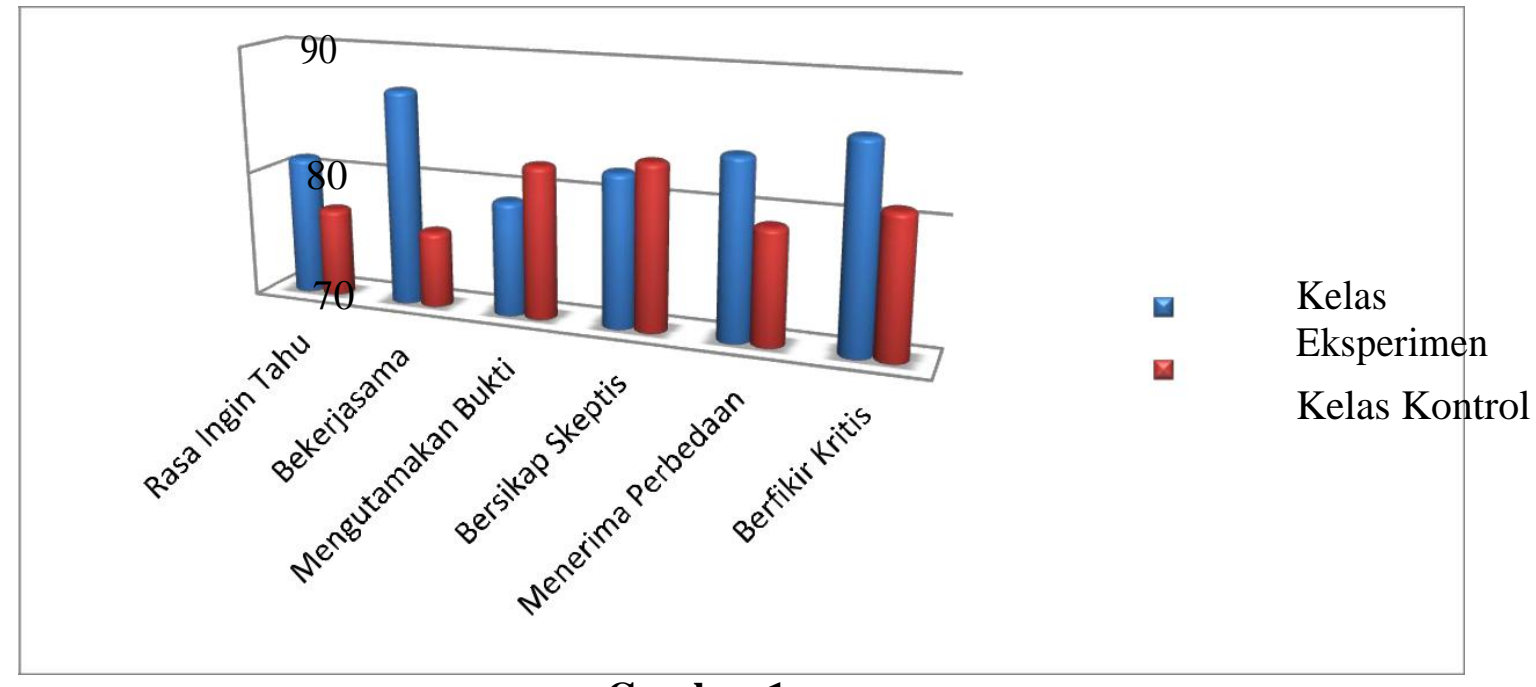

Gambar 1

Diagram Persentase Ketercapaian Angket Sikap Ilmiah

Berdasarkan analisis ketercapaian indikator-indikator sikap ilmiah siswa kelas eksperimen dan kelas kontrol di atas dapat dilihat pada kelas eksperimen diperoleh hasil rataan ketercapaian dari semua indikator sikap ilmiah lebih tinggi dibanding kelas kontrol. Dalam hal ini indikator bekerjasama yaitu pencapaian tertinggi pada kelas eksperimen sedangkan pada kelas kontrol merupakan pencapaian yang terendah. Hal ini dapat terjadi karena pada kelas eksperimen siswa semangat dalam proses pembelajaran karena pada kelas eksperimen pendidik menggunakan model Learning Cycle Tipe 7E disertai teknik Talking Stick sedangkan pada kelas kontrol siswa kurang mengutamakan kerjasama kelompok dalam proses pembelajaran. Pada kelas kontrol pendidik menggunakan model pembelajaran Direct Intruction (DI). Setelah mengetahui hasil sikap ilmiah siswa melalui angket sikap ilmiah, selanjutnya dapat diketahui hasil sikap ilmiah melalui lembar observasi sikap ilmiah, berikut ini :

Tabel 3

Hasil Lembar Observasi Sikap Ilmiah siswa

\begin{tabular}{|l|c|c|}
\hline \multirow{2}{*}{ Kriteria } & \multicolumn{2}{|c|}{ Nilai Lembar Observasi } \\
\cline { 2 - 3 } & Kelas Eksperimen & Kelas Kontrol \\
\hline
\end{tabular}




\begin{tabular}{|l|c|c|}
\hline Nilai tertinggi & 96 & 93 \\
\hline Nilai terendah & 57 & 58 \\
\hline Jumlah & 1927 & 1640 \\
\hline Rataan & 81 & 76 \\
\hline
\end{tabular}

Berdasarkan Tabel 3 di atas dapat dilihat bahwa nilai hasil lembar observasi sikap ilmiah siswa yang diperoleh kelas eksperimen dan kelas kontrol memiliki perbedaan. Nilai lembar observasi sikap ilmiah siswa kelas eksperimen lebih tinggi dari kelas control. Untuk nilai rataan hasil lembar observasi sikap ilmiah siswa kelas eksperimen yaitu 81 dan untuk kelas kontrol nilainya 76. mengutamakan bukti sebesar 74,72 dan indikator ketercapaian terendah adalah bersikap skeptis sebesar 74,44 \%.

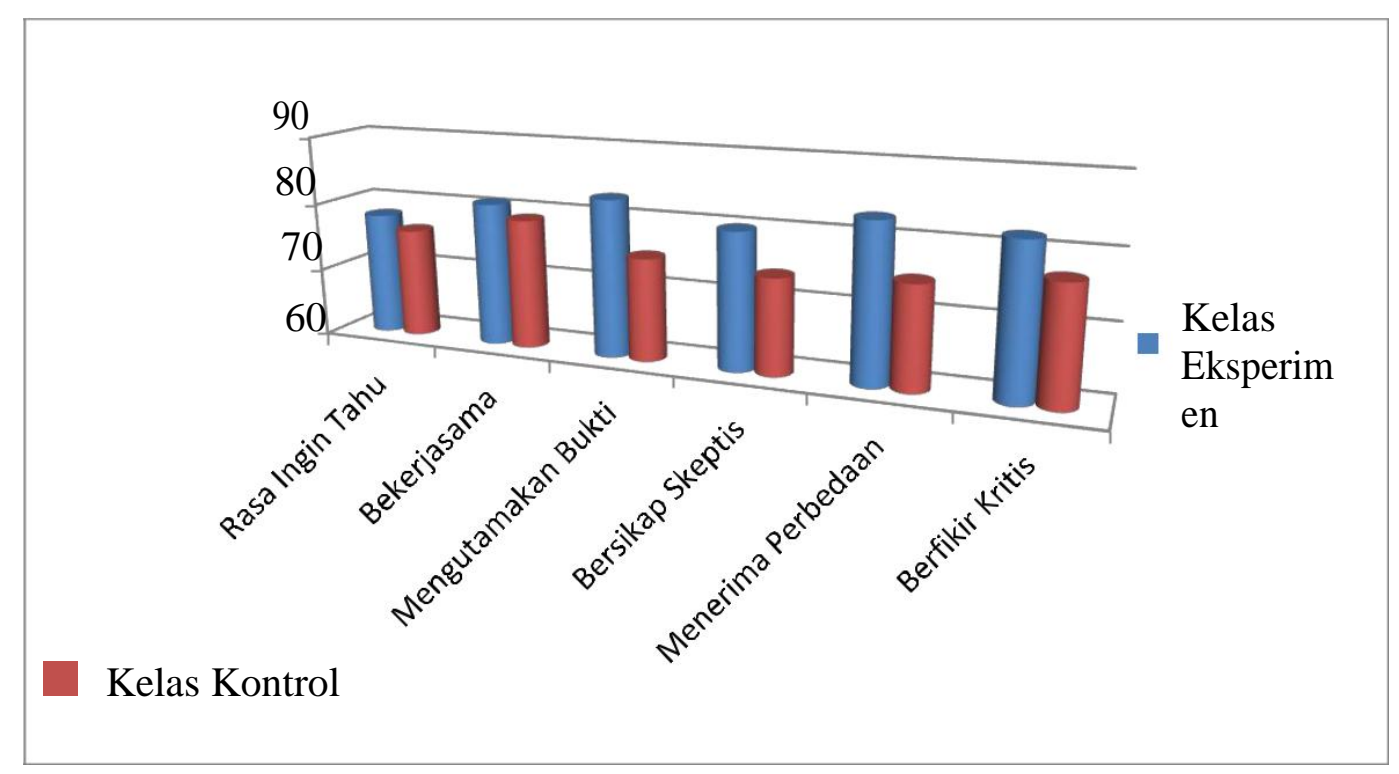

\section{Gambar 4.3}

\section{Diagram Persentase Ketercapaian Lembar Observasi Sikap Ilmiah}

Berdasarkan dari analisis ketercapaian indikator-indikator sikap ilmiah siswa kelas eksperimen dan kelas kontrol yang dilihat dari hasil lembar observasi sikap ilmiah siswa, data tersebut juga menunjukkan peningkatan sikap ilmiah pada kelas eksperimen lebih tinggi daripada kelas kontrol selama 3 kali pertemuan. Dalam hal ini indikator menerima perbedaan yaitu persentase pencapaian tertinggi pada kelas eksperimen sedangkan pada kelas kontrol merupakan persentase pencapaian tertinggi adalah indikator bekerja sama. Selanjutnya menentukan nilai sikap ilmiah siswa, hasil nilai sikap ilmiah siswa ditentukan berdasarkan gabungan nilai yang didapat dari angket sikap ilmiah siswa dan nilai dari hasil lembar observasi sikap ilmiah siswa, agar dapat 
dilihat kesesuaian instrument penelitian antara angket dan lembar observasi sikap ilmiah selama proses pembelajaran. Adapun hasilnya berikut ini :

\section{Tabel 4}

Hasil Sikap Ilmiah siswa

\begin{tabular}{|c|c|c|c|c|}
\hline No. & Kategori & Nilai Sikap & \multicolumn{2}{|c|}{ Kelas } \\
\cline { 4 - 5 } & & Ilmiah & Eksperimen & Kontrol \\
\hline 1. & Sangat Tinggi & $85-100$ & 8 Orang & 5 Orang \\
\hline 2. & Tinggi & $70-84$ & 24 Orang & 17 Orang \\
\hline 3. & Sedang & $55-69$ & 1 Orang & 8 Orang \\
\hline 4. & Rendah & $40-54$ & - & - \\
\hline 5. & Sangat Rendah & $25-39$ & - & - \\
\hline \multicolumn{2}{r}{ Rataan } & $\mathbf{8 2 , 0 3}$ & $\mathbf{7 7 , 8 8}$ & \\
\hline
\end{tabular}

Berdasarkan Tabel 4 di atas hasil sikap ilmiah pada kelas eksperimen yang berjumlah 33 siswa diperoleh rataan sebesar 82,03, dimana 8 orang diantaranya memiliki kategori sikap ilmiah sangat tinggi, 24 orang memiliki kategori sikap ilmiah tinggi dan 1 orang memiliki kategori sikap ilmiah sedang. Sedangkan kelas kontrol yang berjumlah 30 siswa diperoleh rataan sebesar 77,88 , dimana 5 orang diantaranya memiliki kategori sikap ilmiah sangat tinggi, 17 orang memiliki kategori sikap ilmiah tinggi dan 8 orang memiliki kategori sikap ilmiah sedang. Selanjutnya digunakan uji normalitas sebagi berikut :

Tabel 4.8

Hasil Uji Normalitas

\begin{tabular}{|l|r|r|c|c|}
\hline Karakteristik & \multicolumn{2}{|c|}{ Sikap Ilmiah } & \multirow{2}{*}{ Hasil } & Interpretasi \\
\cline { 2 - 3 } & $\begin{array}{c}\text { Kelas } \\
\text { Eksperimen }\end{array}$ & Kelas Kontrol & & \\
\hline$L_{\text {hitung }}$ & 0,1229 & 0,1378 & \multirow{2}{*}{$L_{\text {hitung }}<L_{\text {tabel }}$} & $\begin{array}{c}\text { Berdistribusi } \\
\text { normal }\end{array}$ \\
\hline$L_{\text {tabel }}$ & 0,1518 & 0,159 & \\
\hline
\end{tabular}

Berdasarkan pada ketentuan pengujian hipotesis normalitas, yaitu jika $L_{\text {hitung }}<L_{\text {tabel }}$ maka dinyatakan bahwa data berdistribusi normal. Selanjutnya uji homogenitas sebagai berikut :

Tabel 4.9

Hasil Uji Homogenitas

\begin{tabular}{|c|c|c|c|}
\hline Karakteristik & Hasil Sikap Ilmiah & Hasil & Interpretasi \\
\hline$F_{\text {hitung }}$ & 1,231 & \multirow{2}{*}{$F_{\text {hitung }}<F_{\text {tabel }}$} & Homogen \\
\hline$F_{\text {tabel }}$ & 1,8232 & \\
\hline
\end{tabular}

Berdasarkan tabel hasil uji homogenitas hasil sikap ilmiah siswa, dapat dilihat bahwa $F_{\text {hitung }} 1,231<F_{\text {tabel }} 1,8232$ sehingga $F_{\text {hitung }}<F_{\text {tabel }}$ dan dapat dinyatakan bahwa data tersebut homogen. 
Setelah melakukan uji normalitas dan uji homogenitas maka dilakukan pengujian hipotesis pada tabel dibawah ini :

Tabel 4.10

Hasil Hipotesis Uji t Polled Varians

\begin{tabular}{|c|c|c|c|}
\hline \multicolumn{2}{|c|}{ Karakteristik } & Interpretasi & $\mathrm{H}_{1}$ \\
\hline$t_{\text {hitung }}$ & $t_{\text {tabel }}$ & & \\
\hline 2,4376 & 1,9996 & $t_{\text {hitung }} 2,4376>t_{\text {tabel }} 1,9996$ & diterima \\
\hline
\end{tabular}

Kesimpulan uji $t$ dilihat dengan membandingkan antara $t_{\text {hitung }}$ dan $t_{\text {tabel }}$. Jika $t_{\text {hitung }}$ $>t_{\text {tabel }}$, maka $\mathrm{H}_{\mathrm{o}}$ ditolak dan $\mathrm{H}_{\mathrm{I}}$ diterima. yaitu 2,437617> 1,999624 dengan ini menunjukkan bahwa hipotesis diterima, artinya model Learning Cycle Tipe $7 E$ disertai teknik Talking Stick berpengaruh terhadap sikap ilmiah siswa pada pembelajaran Biologi pada materi Protista.

\section{PEMBAHASAN}

Proses pembelajaran pada kelas eksperimen menggunakan model Learning Cycle Tipe $7 E$ disertai teknik Talking Stick, tipe $7 E$ pada model Learning Cycle adalah elicit, engage, explore, explain, elaborate, evaluate, dan extend. Pada teknik talking stick yaitu tongkat berbicara akan berpindah dari satu siswa ke siswa lain, dalam hal ini peneliti menggunakan dua cara yaitu pertama guru menunjuk siswa dan siswa yang ditunjuk atau yang mendapat talking stick harus memegang talking stick dan harus menjawab pertanyaan yang diberikan guru begitu seterusnya sambil guru berkeliling kelas dan menunjuk siswa secara acak. Cara ini digunakan pada tahapan pembelajaran pada fase elicit, engage, dan evaluate. Sedangkan cara kedua talking stick dipegang oleh siswa secara bergiliran sambil siswa menghitung angka dari 1 (satu) sampai seterusnya, ketika guru mengatakan "stop" maka siswa yang terakhir memegang talking stick harus menjawab pertanyaan, mengemukakan pendapat atau mempresentasikan sesuai dengan apa yang guru perintahkan.

Berdasarkan hasil nilai posttest angket sikap ilmiah siswa diperoleh ketercapaian indikator-indikator sikap ilmiah kelas eksperimen indikator ketercapaian tertinggi adalah bekerjasama sebesar 86,96 \%, kemudian berfikir kritis sebesar 86,36 \%, menerima perbedaan sebesar $83,71 \%$, bersikap skeptis sebesar $82,00 \%$, rasa ingin tahu sebesar 80,55 \% dan indikator ketercapaian terendah adalah mengutamakan bukti sebesar 79,32 \%. Sedangkan ketercapaian indikator-indikator sikap ilmiah kelas kontrol indikator ketercapaian tertinggi adalah bersikap skeptis sebesar 82,91\%, kemudian 
mengutamakan bukti sebesar 82,38 \%, berfikir kritis sebesar 81,04\%, menerima perbedaan sebesar 79,16\%, rasa ingin tahu sebesar 76,52\% dan indikator ketercapaian terendah adalah bekerjasama sebesar 76,33\%.

Berdasarkan hasil penelitian dan perhitungan hasil nilai dari angket posttest sikap ilmiah dan diperoleh persentase ketercapaian indikator-indikator sikap ilmiah siswa kelas eksperimen dan kelas kontrol di atas dapat dilihat pada kelas eksperimen diperoleh hasil rataan ketercapaian dari semua indikator sikap ilmiah lebih tinggi dibanding kelas kontrol. Dalam hal ini indikator bekerjasama yaitu pencapaian tertinggi pada kelas eksperimen sedangkan pada kelas kontrol merupakan pencapaian yang terendah. Hal ini dapat terjadi karena pada kelas eksperimen siswa semangat dalam proses pembelajaran karena pada kelas eksperimen pendidik menggunakan model Learning Cycle Tipe $7 E$ disertai teknik Talking Stick sedangkan pada kelas kontrol siswa kurang mengutamakan kerjasama kelompok dalam proses pembelajaran. Pada kelas kontrol pendidik menggunakan model pembelajaran Direct Intruction (DI).

Berdasarkan nilai lembar observasi sikap ilmiah yang diperoleh siswa dapat dilihat persentase ketercapaian indikator-indikator sikap ilmiah selama pembelajaran pada materi protista pada kelas eksperimen indikator ketercapaian tertinggi adalah menerima perbedaan sebesar 83,08 \%, kemudian mengutamakan bukti sebesar 82,57\%, berfikir kritis $81,56 \%$, bekerjasama sebesar 80,80 \%, bersikap skeptis sebesar 80,30 \% dan indikator ketercapaian terendah adalah rasa ingin tahu sebesar 78,28 \%. Sedangkan pada kelas kontrol indikator yang ketercapaian tertinggi adalah bekerjasama sebesar $78,61 \%$, kemudian berfikir kritis sebesar 76,66 \%, rasa ingin tahu sebesar 75,83\%, menerima perbedaan sebesar 75,27 \%, mengutamakan bukti sebesar 74,72 dan indikator ketercapaian terendah adalah bersikap skeptis sebesar 74,44\%. Setelah menganalisa hasil nilai posttest angket sikap ilmiah dan lembar observasi sikap ilmiah maka terjadi kemunculan indikator pada angket dan lembar observasi tidak sama sehingga menjadi bervariasi tetapi perolehan nilai rataan yang didapatkan pada angket dan lembar observasi tidak jauh berbeda. Selanjutnya menentukan nilai sikap ilmiah siswa sesuai dengan kategori yang telah ditentukan. Sikap ilmiah siswa diperoleh dari hasil gabungan nilai angket sikap ilmiah siswa yang diperoleh dan nilai hasil lembar observasi sikap ilmiah siswa yang diperoleh lalu dibagi rataan. Berdasarkan ketentuan kategori sikap ilmiah siswa pada kelas eksperimen didapatkan nilai sikap ilmiah pada kategori "sangat tinggi" sebanyak 8 orang dan pada kategori "tinggi” sebanyak 24 orang 
dan pada kategori "sedang” sebanyak 1 orang. Pada kelas eksperimen tidak ada yang berada pada kategori rendah dan sangat rendah. Sedangkan kelas kontrol dengan didapatkan pada kategori "sangat tinggi" sebanyak 5 orang, pada kategori "tinggi" sebanyak 17 orang dan pada kategori sedang sebanyak 8 orang. Pada kelas kontrol tidak ada yang berada pada kategori rendah ataupun sangat rendah.

Berdasarkan hasil nilai sikap ilmiah di atas maka dapat disimpulkan bahwa kelas eksperimen berada pada kategori "tinggi" dengan rataan persentase sebesar 82,03\% dan kelas kontrol berada pada kategori "tinggi" dengan rataan persentase sebesar 77,88\%. Kelas eksperimen dan kelas kontrol sama-sama nilai sikap ilmiah yang di dapatkan rataan berada pada kategori "tinggi" tetapi kelas eksperimen mendapatkan nilai yang lebih tinggi dibandingkan kelas kontrol. Hal ini menunjukkan kesesuaian antara angket sikap ilmiah siswa dan hasil lembar observasi sikap ilmiah siswa. Berdasarkan hasil penelitian dan analisa selama proses pembelajaran Biologi dengan materi protista dapat disimpulkan bahwa peningkatan sikap ilmiah pada kelas eksperimen yang menggunakan model Learning CycleTipe 7E lebih tinggi daripada kelas kontrol yang menggunakan model pembelajaran Direct Instruction (DI). Model Learning Cycle Tipe $7 E$ lebih dapat memunculkan sikap ilmiah siswa dalam sintak-sintaknya.

Hasil penelitian ini diperkuat dengan beberapa penelitian yang berkaitan dengan model Learning Cycle Tipe $7 E$ telah banyak dilakukan, antara lain oleh Qulud dkk, penelitiannya menunjukkan bahwa model Learning Cycle Tipe $7 E$ dapat menyajikan konsep pembelajaran yang lebih bermakna serta memberikan respon yang kuat terhadap pembelajaran biologi (Qulud, Wahidin, \& Maryuningsih, 2015). Salah satu penelitian mengenai teknik Talking Stick yaitu penelitian I Gst A A Wahyudiantari dkk, menunjukkan penelitian dengan teknik Talking Stick berpengaruh terhadap hasil belajar siswa pada mata pelajaran IPA (Wahyudiantari, Parmiti, \& Sudhita, 2015). Sehingga keduanya termasuk kedalam pembelajaran kooperatif, keduanya berkombinasi dapat menciptakan suasana menyenangkan dan membuat siswa aktif.

Penelitian menggunakan model Learning Cycle Tipe $7 E$ disertai teknik Talking Stick ini dapat disimpulkan bahwa model pembelajaran ini dapat memberikan respon yang kuat terhadap pembelajaran Biologi dan pada penelitian ini khususnya dapat meningkatkan sikap ilmiah siswa kelas X SMA Negeri 8 Bandar Lampung. Berdasarkan hipotesis yang ingin dicapai peneliti yaitu terdapat pengaruh model 
Learning Cycle Tipe 7E disertai teknik Talking Stick pada materi Protista berpengaruh terhadap sikap ilmiah siswa.

\section{SIMPULAN DAN SARAN}

Berdasarkan hasil penelitian dan pembahasan yang telah dilakukan, maka peneliti dapat menunjukkan bahwa terdapat pengaruh model Learning Cycle Tipe $7 E$ disertai teknik Talking Stick pada materi protista terhadap sikap ilmiah siswa kelas X SMA Negeri 8 Bandar Lampung. Berdasarkan penelitian yang telah dilakukan, ada beberapa hal yang perlu peneliti sarankan yaitu sebagai berikut pendidik dapat menggunakan model Learning Cycle Tipe 7E disertai teknik Talking Stick dalam materi Biologi lain agar dapat mengembangkan inovasi pembelajaran berupa strategi, teknik, model, metode maupun media pembelajaran agar dapat meningkatkan kualitas sikap ilmiah siswa di masa depan. Selanjutnya hendaknya dengan adanya penelitian ini dapat memberikan sumbangan pemikiran untuk meningkatkan mutu pendidikan Biologi dan meningkatkan kualitas pendidik di sekolah dengan menerapkan model Learning Cycle Tipe 7E disertai teknik Talking Stick pada materi pelajaran Biologi.

\section{DAFTAR PUSTAKA}

Agustyaningrum, N. (2011). Implementasi model pembelajaran learning cycle 5E untuk meningkatkan kemampuan komunikasi matematis siswa kelas IX B SMP Negeri 2 Sleman. Seminar Nasional Matematika dan Pendidikan Matematika, 377.

Astutik, S. (2012). Meningkatkan Hasil Belajar Siswa Dengan Model Siklus Belajar (Learning Cycle 5E) Berbasis Eksperimen Pada Pembelajaran Sains Di SDN Patrang I Jember. Jurnal Ilmu Pendidikan Sekolah Dasar, 1(2), 143-153.

Ayu Aningrum, A. (2014). Penerapan Model Pembelajaran Talking Stick Untuk Meningkatkan Hasil Belajar Siswa Pada Kompetensi Dasar Menjelaskan Komunikasi Kelas X Apk1 Di Smk Negeri 2 Nganjuk. Jurnal Administrasi Perkantoran (JPAP), 2(2).

Fu'adi, I. F., \& Eko, B. (2009). Hubungan minat berwirausaha dengan prestasi praktik kerja industri siswa kelas XII Teknik Otomotif SMK Negeri 1 Adiwerna Kabupaten Tegal tahun ajaran 2008/2009. Jurnal Pendidikan Teknik Mesin, 9(2).

Haryoko, S. (2012). Efektivitas pemanfaatan media audio-visual sebagai alternatif optimalisasi model pembelajaran. Jurnal Edukasi Elektro, 5(1).

Hasan, R., Ngatiyo, H., \& Aunurrahman, H. (2013). Penerapan talking stick untuk motivasi belajar mata pelajaran ipa kelas III SDN 04 Pontianak. Jurnal Pendidikan dan Pembelajaran, 2(1). 
Karweti, E. (2010). Pengaruh kemampuan manajerial kepala sekolah dan faktor yang mempengaruhi motivasi kerja terhadap kinerja guru SLB di Kabupaten Subang. Jurnal penelitian pendidikan, 11(2), 77-89.

Kulsum, U., \& Hindarto, N. (2011). Penerapan model learning cycle pada sub pokok bahasan kalor untuk meningkatkan keaktifan dan hasil belajar siswa kelas VII SMP. Jurnal Pendidikan Fisika Indonesia, 7(2).

Qulud, Q., Wahidin, W., \& Maryuningsih, Y. (2015). Penerapan Model Pembelajaran Learning Cycle 7e Untuk Meningkatkan Kemampuan Literasi Sains Siswa Pada Konsep Sistem Reproduksi Kelas Xi Di Sma Negeri 1 Arjawinangun. Scientiae Educatia: Jurnal Pendidikan Sains, 4(1), 21-32.

Rahayuningsih, R., Masykuri, M., \& Utami, B. (2012). Penerapan Siklus Belajar 5E (Learning Cycle 5E) Disertai Peta Konsep Untuk Meningkatkan Kualitas Proses dan Hasil Belajar Kimia Pada Materi Kelarutan dan Hasil Kali Kelarutan Kelas XI IPA Sma Negeri 1 Kartasura Tahun Pelajaran 2011/2012. Jurnal Pendidikan Kimia (JPK), 1(1), 51-58.

Rahmawati, D., Nugroho, S. E., \& Putra, N. M. D. (2014). Penerapan Model Pembelajaran Kooperatif Tipe Numbered Head Together Berbasis Eksperimen untuk Meningkatkan Keterampilan Proses Sains Siswa SMP. UPEJ Unnes Physics Education Journal, 3(1).

Sanjaya, D. H. W. (2016). Penelitian tindakan kelas. Prenada Media.

Sari, A. K. (2014). Analisis Karakteristik Gaya Belajar VAK (Visual, Auditorial, Kinestetik) Mahasiswa Pendidikan Informatika Angkatan 2014. EduticScientific Journal of Informatics Education, 1(1).

Sugiharti, A. (2011). Penerapan Diskusi Kelompok disertai Talking Stick untuk Meningkatkan Aktivitas Oral dan Kemandirian Belajar Biologi Siswa Kelas XJ SMA Negeri 1 Kartasura. Skripsi Tidak Dipublikasikan. Surakarta: FKIP Universitas Sebelas Maret.

Sugiyono. (2015). Metodologi Penelitian Kuantitatif, Kualitatif, dan R\&D. Bandung: CV Alfabeta.

Taufiq, M. (2012). Remediasi Miskonsepsi Mahasiswa Calon Guru Fisika Pada Konsep Gaya Melalui Penerapan Model Siklus Belajar (learning cycle) 5E. Jurnal Pendidikan IPA Indonesia, 1(2).

Wahyudiantari, I. G. A. A., Parmiti, D. P., \& Sudhita, I. W. R. (2015). Pengaruh Model Pembelajaran Kooperatif Tipe Talking Stick Berbantuan Multimedia Pembelajaran Interaktif Dalam Meningkatkan Hasil Belajar IPA. Jurnal EDUTECH Undiksha, 3(1).

Wena, M. (2009). Strategi pembelajaran inovatif kontemporer. Jakarta: bumi aksara.

Yanuarta, L., Waluyo, J., \& Suratno, S. (2014). Penerapan Model Pembelajaran Kooperatif Tipe Think, Talk, Write (TTW) Dengan Teknik Talking Stick Dalam Meningkatkan Karakter Dan Hasil Belajar IPA-Biologi (Siswa Kelas VII-E 
SMP Negeri 2 Kalisat Semester Genap Tahun Ajaran 2012/2013). Pancaran Pendidikan, 3(1), 69-78.

Yumarlin, M. Z. (2013). Pengembangan Permainan Ular Tangga Untuk Kuis Mata Pelajaran Sains Sekolah Dasar. Jurnal Teknik, 3(1), 75-84. 